\title{
The cytological changes of tobacco zygote and proembryo cells induced by beta-glucosyl Yariv reagent suggest the involvement of arabinogalactan proteins in cell division and cell plate formation
}

Miao Yu and Jie Zhao*

\begin{abstract}
Background: In dicotyledonous plant, the first asymmetric zygotic division and subsequent several cell divisions are crucial for proembryo pattern formation and later embryo development. Arabinogalactan proteins (AGPs) are a family of extensively glycosylated cell surface proteins that are thought to have important roles in various aspects of plant growth and development, including embryogenesis. Previous results from our laboratory show that AGPs are concerned with tobacco egg cell fertilization and zygotic division. However, how AGPs interact with other factors involved in zygotic division and proembryo development remains unknown.

Results: In this study, we used the tobacco in vitro zygote culture system and series of meticulous cell biology techniques to investigate the roles of AGPs in zygote and proembryo cell division. For the first time, we examined tobacco proembryo division patterns detailed to every cell division. The bright-field images and statistical results both revealed that with the addition of an exogenous AGPs inhibitor, beta-glucosyl Yariv (beta-GlcY) reagent, the frequency of aberrant division increased remarkably in cultured tobacco zygotes and proembryos, and the cell plate specific locations of AGPs were greatly reduced after beta-GlcY treatment. In addition, the accumulations of new cell wall materials were also significantly affected by treating with beta-GlcY. Detection of cellulose components by Calcofluor white stain showed that strong fluorescence was located in the newly formed wall of daughter cells after the zygotic division of in vivo samples and the control samples from in vitro culture without beta-GlcY treatment; while there was only weak fluorescence in the newly formed cell walls with beta-GlcY treatment. Immunocytochemistry examination with JIM5 and JIM7 respectively against the low- and high-esterified pectins displayed that these two pectins located in opposite positions of zygotes and proembryos in vivo and the polarity was not affected by beta-GlcY . Furthermore, FM4-64 staining revealed that endosomes were distributed in the cell plates of proembryos, and the localization pattern was also affected by beta-GlcY treatment. These results were further confirmed by subsequent observation with transmission electron microscopy. Moreover, the changes to proembryo cell-organelles induced by beta-GICY reagent were also observed using fluorescent dye staining technique.

Conclusions: These results imply that AGPs may not only relate to cell plate position decision, but also to the location of new cell wall components. Correlated with other factors, AGPs further influence the zygotic division and proembryo pattern establishment in tobacco.
\end{abstract}

Keywords: Arabinogalactan protein, Nicotiana tabacum L., $\beta$-GlcY reagent, Zygote, Proembryo, Cell wall

\footnotetext{
* Correspondence: jzhao@whu.edu.cn

State Key Laboratory of Hybrid Rice, College of Life Sciences, Wuhan University, Wuhan 430072, China
}

\section{Ciomed Central}




\section{Background}

Embryogenesis is a fundamental developmental event in the life cycle of flowering plants. In higher plants, embryogenesis consists of two major phases: morphogenesis and maturation. Morphogenesis involves the establishment of the embryo's body plan, while maturation includes cell expansion and accumulation of storage macromolecules prepared for embryo desiccation and germination as well as early seedling growth [1-3]. Embryogenesis originates from the zygotic asymmetric division which results in the formation of a small cytoplasmically-dense apical cell and a larger vacuolated basal cell $[4,5]$. These two distinctsized daughter cells have different cell fates: the apical cell differentiates into an embryo proper that develops into most of the mature embryo, while the basal cell divides into the hypophysis and the suspensor [1]. The hypophysis contributes to the formation of the root meristem within the embryo proper, while the suspensor is a highly specialized, terminally differentiated embryonic organ that plays structural and physiological roles in embryo development, and degenerates at the end of embryogenesis [6-8]. The cause of the different developmental pathways of apical and basal cells remains to be researched.

The crucial concerns in plant embryogenesis research are unraveling the mechanisms that operate the processes of embryonic body plan establishment and different organ specification. The experimental manipulation for embryogenesis of angiosperms is difficult, particularly at the early stage when the embryo develops deeply inside maternal tissues [9]. In recent years, the inaccessibility of some plant embryos has been overcome. Combined with the in vitro culture system, the isolated zygotes simulate normal developmental patterns and permit direct molecular analysis at any of the early embryonic stages [10-14]. In the past few years, in our laboratory, the fertilized ovules $[15,16]$, zygotic embryos $[17,18]$ and even isolated zygotes $[15,19]$ were in vitro cultured and used to study developmental events of different staged embryos. Compared with Arabidopsis thaliana, zygotes and proembryos in tobacco provide an ideal model system for investigating early embryo development, since they are relatively larger than those of Arabidopsis thaliana and can be easily isolated [15]. Recently, we extracted mRNAs from tobacco apical and basal cells to generate cDNA libraries and investigated the transcript profiles of the two daughter cells from zygotes by an expressed sequence tag analysis [20]. The strategy of combining an in vitro culture system with genetic and molecular techniques should allow us to obtain new insight into early embryo development events and embryo cell fate decision in flowering plants.

Angiosperm embryo development follows a predictable pattern and numbers of cell divisions [3,21]. In higher plants, cytokinesis is the process of separating cytoplasm through the formation of a new plasma membrane and cell wall between daughter cells [22,23]. The major stages of plant cell division contain preprophase band (PPB) formation, phragmoplast (PHP) emergence, cell plate expansion and new cell wall location. Recent studies revealed that endocytic delivery of the cell surface material significantly contributes to cell plate formation during plant cell division [22]. New cell wall components, such as pectin and wall-associated proteins (e.g. arabinogalactan proteins-AGPs), are transferred to the margin of the cell plate via endosomes [24-26]. Eventually, the expanding cell plate fuses with the parental plasma membrane at the division site, and then separates the two daughter cells.

AGPs are a large family of highly glycosylated proteins thought to be involved in plant growth and development [27-32]. In Arabidopsis, the organ-, tissue- and cell-type specific expression patterns indicate that AGPs are markers of cell identity and fate decision [33-35]. $\beta$-glucosyl Yariv ( $\beta$-GlcY) reagent is used as an AGP inhibitor to determine AGP function by specific binding and blocking $[36,37]$. Although the precise effect of the $\beta$-GlcY is unknown, it is possible that the formation of large complexes at the cell surface prevents the normal assembly of molecules into cell wall [38]. In our laboratory, the previous studies have revealed that $\beta$-GlcY treatment can change the first zygotic division pattern from asymmetric to symmetric [15]. The in vitro tobacco zygote culture system with $\beta$-GlcY treatment provided us with an ideal model which might shed light on our research in the early proembryo development of higher plants. In order to delve further into this important developmental event, the molecular and cellular studies were both carried out. Recently, our transcriptome study on $\beta$-GlcY treated zygotes and two-celled proembryos also revealed that $\beta$-GlcY affected the expression of some genes related to zygotic division and proembryonic development [39].

As a continuous study of the previous work, in this paper, we used the tobacco in vitro zygote culture system and series of meticulous cell biology techniques to investigate the roles of AGPs in zygote and proembryo cell division. We adopted $\beta$-GlcY reagent to perturb AGPs function for in vitro cultured zygotes and proembryos of tobacco (Nicotiana tabacum L.). Both immunofluorescence detection with antibody JIM13 and staining with the $\beta$-GlcY reagent showed that AGPs distributed in the new cell plate during normal in vitro zygotic division. Cellular staining with Calcofluor white $(\mathrm{CW})$ reagent (for observing cellulosic components), and fluorescent labeling with JIM5 and JIM7 monoclonal antibodies (for detecting low-esterified and high-esterified pectins, respectively) against both in vivo and in vitro proembryos demonstrated that $\beta$-GlcY treatment affected the location of cellulose deposits but not pectin polar distribution in the new cell wall. Furthermore, FM4-64 staining indicated that endocytic vesicles distributed in the cell plate when 
proembryo cells were dividing. The results imply that AGPs may be involved in the formation of new embryo cell plate. A possible model involving the relationship between AGPs and the other regulation factors was proposed and discussed.

\section{Methods}

Plant materials

Tobacco (Nicotiana tabacum L.) cultivar SR-1 was used as material. The plantlets grew in a glasshouse at $26 \pm 1^{\circ} \mathrm{C}$ in a 16/8 h light/dark regime. The flowers were artificially pollinated during anthesis.

\section{Isolation of zygotes and proembryos in vivo}

Zygotes and proembryos were isolated according to $\mathrm{Li}$ et al. [40]. Fertilized ovules at different developmental stages (3.5, 4, 4.5 and 5 days after pollination; DAP) were collected for isolating zygotes and proembryos. Firstly, ovules were placed into the enzymatic solution containing 10-13\% mannitol, $3 \mathrm{mM}$ MES, $1 \%$ cellulase R-10, and $0.8 \%$ macerozyme $\mathrm{R}-10, \mathrm{pH} 5.7$ for $30 \mathrm{~min}$ at $25^{\circ} \mathrm{C}$. Then, ovules were gently ground with a small glass pestle, and embryo sacs were dissociated from the macerated ovules. After a short-term treatment of an enzymatic solution containing $13 \%$ mannitol, $3 \mathrm{mM}$ MES, $0.25 \%$ cellulose $\mathrm{R}-10$ and $0.2 \%$ macerozyme $\mathrm{R}-10, \mathrm{pH} 5.7$, zygotes or proembryos were isolated from embryo sacs by microdissection, and transferred into fixing solution for further experiments.

\section{Zygote culture in vitro}

The detailed procedure of zygote culture in vitro was performed according to Qin and Zhao [15]. In zygote culture, $\beta$-GlcY reagent (Biosupplies Pty Ltd) was added to medium at a final concentration of $50 \mu \mathrm{M}$, and control tests performed by omitting the reagent. The medium was composed of the MS main salts plus KM8p minimal salts, organic elements, and vitamins (Sigma) $(\mathrm{pH} 5.8)$, and supplemented with $0.3 \mathrm{~mol} / \mathrm{L}$ sucrose, $0.15 \mathrm{~mol} / \mathrm{L}$ mannitol, $0.1 \mathrm{~mol} / \mathrm{L}$ sorbitol, $1 \mathrm{~mol} / \mathrm{L} \mathrm{2,4-D,}$ $0.5 \mathrm{~mol} / \mathrm{L} 6-\mathrm{BA}$ and $10 \%$ coconut (Sigma).

The isolated zygotes were cultured in a millicell (containing $150 \mu \mathrm{L}$ of medium) with a semi-permeable membrane (Millicell-CM 0.4 $\mathrm{M}$ M PICM01250, diameter $12 \mathrm{~mm}$ ), with the millicell placed in middle of a $35-\mathrm{mm}$ Petri dish with $1.5 \mathrm{~mL}$ of medium containing $100-120$ ovules at 4 DAP as feeder cells. After being cultured at $25^{\circ} \mathrm{C}$ in darkness for 0.5-3 d, the zygotes and proembryos were respectively collected for the next experiments.

\section{Immunofluorescent labeling of AGPs and pectins}

The MAbs JIM5, JIM7 and JIM13 were generously provided by Prof. Paul Konx. JIM5 was used to recognize a polygalacturonic acid (low-esterified pectin) epitope,
JIM7 a methylester-containing pectin epitope [41], and JIM13 for glycosyl moieties of AGPs. The samples were fixed gradually in a series of paraformaldehyde with increasing concentrations at $0.5,1,2$ and $4 \%$ in phosphatebuffered saline (PBS pH 7.4, $2.68 \mathrm{mM} \mathrm{KCl}, 1.47 \mathrm{mM}$ $\mathrm{KH}_{2} \mathrm{PO}_{4}, 136.9 \mathrm{mM} \mathrm{NaCl}, 8.1 \mathrm{mM} \mathrm{Na} \mathrm{HPO}_{4}$, and $10-13 \%$ mannitol) for $10 \mathrm{~min}$ in each step. After three rinses with PBS buffer ( $\mathrm{pH} 7.4)$, the fixed samples were incubated with the primary MAbs JIM5, JIM7 or JIM13 diluted 1:10 in antibody dilution buffer containing PBS buffer with $0.8 \%$ bovine serum albumin (BSA), overnight at $4^{\circ} \mathrm{C}$. Subsequently, the samples were rinsed in PBS buffer three times (5 min each) and incubated with secondary antibodies at 1:100 concentrations in antibody dilution buffer (PBS buffer with 0.8\% BSA) for $2 \mathrm{~h}$ in darkness at room temperature. Control samples were incubated with antibody dilution buffer omitting the primary antibody.

\section{Staining of cell walls}

Calcofluor white ST (CW; America Cyanamid Co.) was used as a cellulosic wall component marker. CW stock solution (1\% in bidistilled water, $\mathrm{pH} 10-11$, adjusted with $\mathrm{NaOH}$ ) was diluted 10 times in PBS buffer ( $\mathrm{pH} 7.4)$ as a working solution. The fixed samples were incubated with CW working solution in darkness for $10 \mathrm{~min}$, washed twice with PBS buffer and observed under a microscope.

\section{Staining for nuclear location}

After the MAbs incubation or dye staining, the samples were incubated in $5 \mu \mathrm{g} / \mathrm{mL}$ 4,6-diamidino-2-phenylindole (DAPI; Molecular Probes) dissolved in PBS buffer ( $\mathrm{pH} 7.4$ ) for $10 \mathrm{~min}$, and then washed twice with PBS buffer. DAPI stock solution ( $1 \mathrm{mg} / \mathrm{mL}$ in bidistilled water) was stored in darkness at $4^{\circ} \mathrm{C}$.

\section{Labeling endomembrane vesicles}

The samples were incubated with $5 \mu \mathrm{g} / \mathrm{mL}$ FM4-64 [N-(3triethylammoniumpropyl)-4- (p-diethylam-inophenylhexatrienyl)-phridinium-2Br; Molecular Probes] for $20 \mathrm{~min}$ at room temperature. The stock solution was prepared at a concentration of $1 \mathrm{mg} / \mathrm{mL}$ FM4-64 in dimethyl sulfoxide (DMSO, Amrasco; stored at $-20^{\circ} \mathrm{C}$ ) and the working solution dissolved in PBS buffer ( $\mathrm{pH} 7.4$ ) with 10-13\% mannitol for labeling of endomembrane vesicles [42].

\section{Labeling endoplasmic reticulum}

The stock solution was prepared by dissolving $1 \mathrm{mg}$ $\mathrm{DiOC}_{6}(3)$ in $1 \mathrm{~mL}$ of ethanol, and diluted 200 times in PBS buffer ( $\mathrm{pH}$ 7.4) for staining samples. The fixated samples were stained with $2 \mu \mathrm{g} / \mathrm{mL} 3,3$ '-dihexyloxacarbocyanine iodide $\left[\mathrm{DiOC}_{6}(3)\right.$; Alexis] for $5 \mathrm{~min}$ and observed under confocal laser scanning microscopy (CLSM). 


\section{Labeling mitochondria}

The vital dye Rhodamine123 (Sigma) was used to observe mitochondria. Rhodamine123 was dissolved in DMSO at $1 \mathrm{mg} / \mathrm{mL}$ for stock solution. The living samples were stained by $10 \mu \mathrm{g} / \mathrm{mL}$ Rhodamine123 dissolved in PBS buffer (containing 10-13\% mannitol at $\mathrm{pH} 7.4$ ) for $10 \mathrm{~min}$ at room temperature, and washed three times with PBS buffer.

\section{Light microscopy and image collection}

The samples were observed under an inverted microscope (Leica DMIRB), and the images recorded by a cooled CCD (Micro MAX Princeton Instruments Inc.) or a confocal laser scanning microscope (FluoView $^{\mathrm{TM}}$ FV1000, Olympus).

\section{Transmission electron microscopy (TEM)}

In vivo samples: the isolated ovules at 3-4 DAP were fixed in $3 \%$ glutaraldehyde and PBS (pH 7.4) under vacuum at room temperature for $2 \mathrm{~h}$, and then kept in fresh fixative for 4-6 h. After several rinses with PBS buffer, the samples were post-fixed in $1 \%$ osmium tetroxide at $4^{\circ} \mathrm{C}$ overnight, then dehydrated in a series of ethanol gradients, and embedded in Spurr resin. Resin polymerization was carried out at $65^{\circ} \mathrm{C}$ overnight. Ultrathin sections $(60-70 \mathrm{~nm})$ were cut under a Sorvall MT-6000 ultramicrotome using glass knives and collected onto Formvar-coated copper grids. The sections were examined and photographed under a transmission electron microscope (H-800; Hitachi).

In vitro samples: the zygotes and proembryos cultured in vitro were collected and fixed gradually in a series of increasing concentrations of $0.5,1$ and $2 \%$ glutaraldehyde in PBS (pH 7.4) for each step in $30 \mathrm{~min}$, then embedded into $2 \%$ agar and fixed in fresh fixative for $3 \mathrm{~h}$. The postfixation, dehydration, embedding and the later procedures were performed according to the above described method.

\section{Result}

\section{Pattern of early proembryo formation in tobacco}

Initially, we examined early proembryo division patterns in vivo for tobacco. After the egg cell was fertilized, the zygote formed, subsequently elongated (Figure $1 \mathrm{~A}_{1}$ ) and underwent an asymmetrical transverse division to produce a small, spherical apical cell and a larger, elongated basal cell (Figure $1 \mathrm{~B}_{1}$ ). Both the apical and basal cells underwent a transverse division to generate three- and four-celled proembryos (Figure $1 C_{1}, D_{1}$ ). In the fourcelled stage, two longitudinal divisions of the two upper cells produced an octant embryo-proper (Figure $1 \mathrm{E}_{1}, \mathrm{~F}_{1}$ ). Then, the eight cells of the embryo-proper periclinally divided and gave rise to 16-celled embryo-proper (data not shown). The basal cell underwent two transverse divisions to form the suspensor, composed of a single line of four cells (Figure $1 \mathrm{~F}_{1}$ ). Using DAPI staining as a guide, the nuclei in proembryos were observed, and served as a marker for rapidly determining the cell number and relative position (Figure $1 \mathrm{~A}_{2}-\mathrm{F}_{2}$ ).

\section{Proembryo division pattern change induced by treatment of $\beta$-GIcY reagent}

Tobacco zygotes were isolated and cultured in vitro to observe the changes in proembryo cell division after treatment with $\beta$-GlcY reagent (Figure $2 \mathrm{~A}_{1}, \mathrm{~A}_{2}$ ). In treated samples, $70.36 \%$ of zygotes $(n=496)$ completed the first division, compared to $70.80 \%$ in untreated samples $(\mathrm{n}=185)$. After $2-3 \mathrm{~d}$ of in vitro culture, $37.71 \%$ of treated zygotes divided into multicellular proembryos, versus $31.67 \%$ in control culture (Figure 2K). After $50 \mu \mathrm{M} \beta$-GlcY reagent was added into the medium, the position of cell plate for the first division of zygotes (Figure $2 B_{1}, C_{1}, B_{2}, C_{2}$ ) differed from that of untreated zygotes (Figure $2 G_{1}, G_{2}$ ). The abnormal position of the cell division plane resulted in forming two equal cells or a larger apical cell relative to the basal cell (Figure $2 \mathrm{~B}_{1}, \mathrm{C}_{1}, \mathrm{~B}_{2}, \mathrm{C}_{2}$ ). In contrast, most untreated elongated zygotes asymmetrically divided into two-celled proembryos (Figure $2 \mathrm{G}_{1}, \mathrm{G}_{2}$ ), similar to the natural division pattern of zygotes in vivo (Figure $1 \mathrm{~B}_{1}$ ). Among the 185 untreated zygotes, the frequency of the first asymmetrical division was up to $60 \%$, but symmetric division reached only $10.80 \%$ (Figure $2 \mathrm{~K}$ ). However, the treated samples had a significantly higher percentage (approximately 50\%) of abnormal two-celled proembryos compared with untreated samples (Figure 2K).

The subsequent proembryo cell divisions were also affected by the $\beta$-GlcY treatment, with the cell division plane occurring in apparently random directions. After $2-3 \mathrm{~d}$ of culture, nearly one-third of the zygotes divided into 3-5-celled proembryos (Figure $2 \mathrm{~K}$ ). In $\beta$-GlcY treated samples, 27.62\% 3/4-celled proembryos divided aberrantly (Figure $2 \mathrm{D}_{1}, \mathrm{E}_{1}, \mathrm{D}_{2}, \mathrm{E}_{2}$; Figure $2 \mathrm{~K}$ ), and $4.79 \%$ proembryos became a budded structure (Figure $2 \mathrm{~F}_{1}, \mathrm{~F}_{2}$; Figure $2 \mathrm{~K}$ ), while the frequency of normal proembryos decreased to $3.33 \%$ (Figure 2K). In contrast, most untreated zygote cells normally divided as per the natural division pattern in vivo and formed an embryo proper (Figure $2 \mathrm{H}_{1}-\mathrm{J}_{1}, \mathrm{H}_{2}-\mathrm{J}_{2}$ ), serving as an important control. The data in Figure $2 \mathrm{~K}$ illustrates that $\beta$-GlcY does not affect the survival rate and cell division frequency, but specifically has influence on cell plate position decision of tobacco zygotes and proembryos, suggesting that AGPs may be involved in zygote division and early proembryo pattern formation.

\section{The influence of $\beta$-GIcY reagent on AGPs distribution}

By using the monoclonal antibodies JIM13 and $\beta$-GlcY reagent, we could detect the AGPs distribution in proembryos. The cell plates of proembryos were stained a red color (Figure $3 \mathrm{E}_{2}-\mathrm{G}_{2}$ ) with $\beta$-GlcY treatment, and the distribution pattern was similar to the fluorescent 

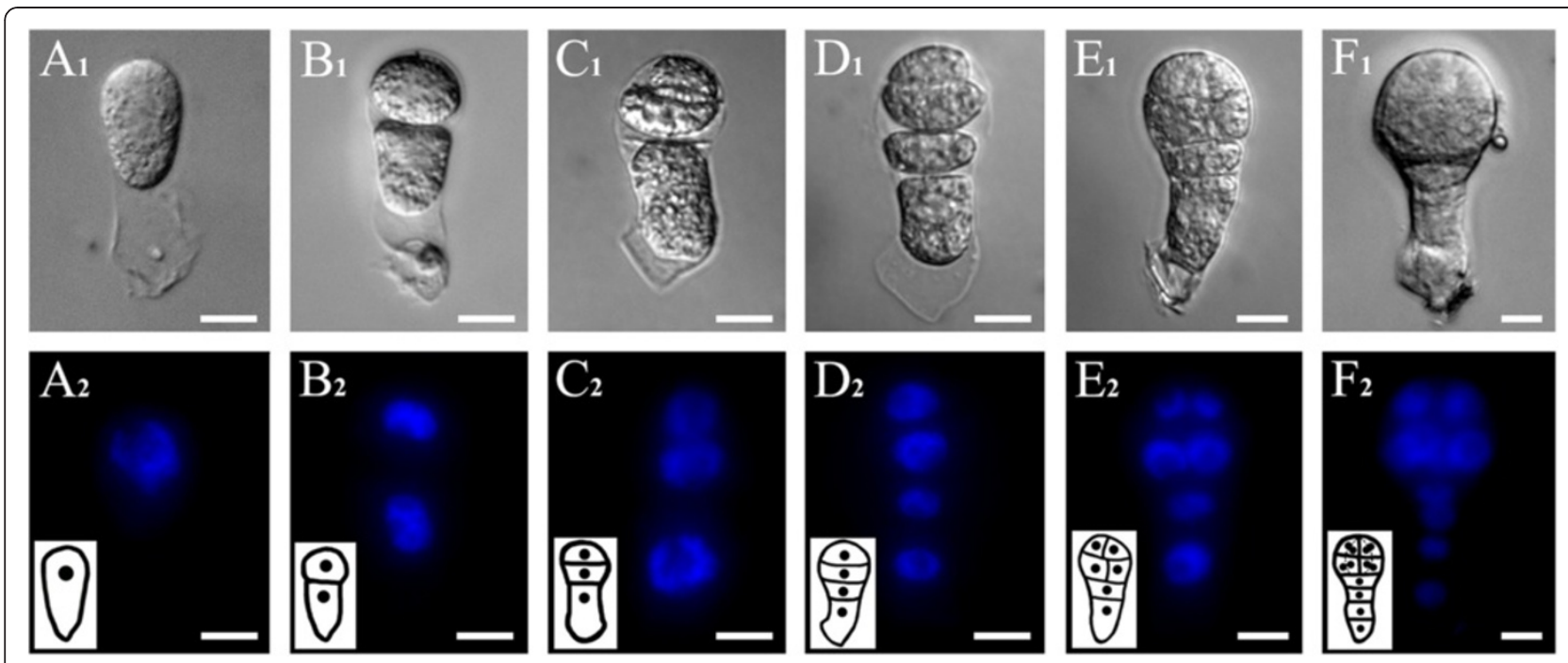

Figure 1 Cell division pattern of zygote and proembryo in tobacco. $\left(A_{1}-H_{1}\right)$ Bright-field images. $\left(A_{2}-H_{2}\right)$ Fluorescence images of DAPI-stained nuclei corresponding to bright-field images. $\left(\mathbf{A}_{\mathbf{1}}\right.$ and $\left.\mathbf{A}_{\mathbf{2}}\right) \mathrm{A}$ isolated live zygote at $84 \mathrm{~h}$ after pollination. $\left(\mathbf{B}_{\mathbf{1}}\right.$ and $\left.\mathbf{B}_{\mathbf{2}}\right) \mathbf{A}$ two-celled proembryo with a small apical cell and a large basal cell from a zygote asymmetrical division. $\left(\mathbf{C}_{\mathbf{1}}\right.$ and $\left.\mathbf{C}_{\mathbf{2}}\right)$ A three-celled proembryo with a large basal cell and two-celled embryo-proper after apical cell division. $\left(\mathbf{D}_{\mathbf{1}}\right.$ and $\left.\mathbf{D}_{\mathbf{2}}\right)$ A four-celled proembryo with a two-celled embryo-proper and a two-celled suspensor. ( $\mathbf{E}_{\mathbf{1}}$ and $\mathbf{E}_{\mathbf{2}}$ ) A proembryo with an eight-celled embryo-proper and a two-celled suspensor. $\left(\mathbf{F}_{\mathbf{1}}\right.$ and $\left.\mathbf{F}_{\mathbf{2}}\right)$ A multicellular proembryo with a four-celled suspensor. The inserted pictures in $\mathbf{A}_{\mathbf{2}}-\mathbf{F}_{\mathbf{2}}$ are schematic diagrams of zygotes and proembryos. Bars $=10 \mu \mathrm{m}$.

result of JIM13 epitopes (Figure $3 \mathrm{~B}_{1}-\mathrm{D}_{1}$ ), both indicating abundant AGPs in the newly generated cell plate. Compared with in vivo (Figure $3 \mathrm{~A}_{1}-\mathrm{D}_{1}$ ) and in vitro untreated proembryos (Figure $3 \mathrm{H}_{1}$ ), the immunofluorescence in the treated proembryo cells (Figure $3 \mathrm{E}_{1}-\mathrm{G}_{1}$ ) was remarkably weakened, especially in cell plate regions, suggesting that $\beta$-GlcY specifically bound the carbohydrate of AGPs, and then could obstruct its binding with monoclonal antibody JIM13. In addition, a negative control without primary antibody showed no fluorescence in samples (data not shown).

\section{The polar distribution of pectins in zygotes and proembryos in vivo and in vitro}

Monoclonal antibodies JIM5 and JIM7 bind to distinct partially methylesterified epitopes of pectic homogalacturonan (HG), with JIM5 for low-esterified and JIM7 for high-esterified pectins. In tobacco zygotes and proembryos, the two pectins displayed different distributions (Figures 4 and 5). For in vivo zygotes, the labeling of JIM5 showed low-esterified pectins distributed mainly in the basal end (or micropylar end) cell wall of the, but markedly weaker distribution in the cytoplasm and apical end (or chalazal end) cell wall (Figure $4 \mathrm{~A}_{1}$ ). After the zygotes division, the immunofluorescence was more concentrated in the basal end of the cell walls (Figure $4 B_{1}-D_{1}$ ). Furthermore, in the in vitro cultured zygotes and proembryos, JIM5 immunofluorescence also showed that low-esterified pectin was mainly distributed in the basal end cell wall (Figure $4 \mathrm{E}_{1}-\mathrm{G}_{1}$ ). The distribution patterns of low-esterified pectin were similar between the treated (Figure $4 \mathrm{E}_{1}, \mathrm{~F}_{1}$ ) and untreated samples (Figure $4 G_{1}$ ). Thus, there was no difference in distribution of the low-esterified pectin between in vivo and in vitro cultured zygotes and proembryos, and we may conclude that $\beta$-GlcY did not affect the distribution of the low-esterified pectin.

In contrast with JIM5, the labeling of JIM7 displayed a different distribution pattern (Figure 5). For in vivo zygotes, JIM7 immunofluoresence was located in the entire cell wall and was slightly weaker in the cytoplasm (Figure $5 \mathrm{~A}_{1}$ ). After zygotic division, the fluorescence of high-esterified pectin gradually concentrated to the apical end of in vivo proembryos (Figure $5 \mathrm{~B}_{1}-\mathrm{D}_{1}$ ). In in vitro cultured proembryos (Figure $5 \mathrm{E}_{1}-\mathrm{G}_{1}$ ), the immunofluorescence showed high-esterified pectin distribution patterns were similar between the treated (Figure $5 \mathrm{E}_{1}, \mathrm{~F}_{1}$ ) and untreated samples (Figure $5 \mathrm{G}_{1}$ ); however, there were differences with in vivo proembryos (Figure $5 \mathrm{~B}_{1}-\mathrm{D}_{1}$ ). For in vitro cultured proembryos, high-esterified pectins distributed in whole cell walls of $\beta$-GlcY treated (Figure $5 \mathrm{E}_{1}, \mathrm{~F}_{1}$ ) or not treated samples (Figure $5 \mathrm{G}_{1}$ ). The JIM7 immunofluorescence revealed that in vitro culture could alter the distribution pattern of highesterified pectins.

\section{Cellulose accumulation change induced by treatment of $\beta$-GlcY reagent}

To observe the cellulose distribution in zygotes and proembryos in vivo and in vitro, we used Calcofluor white $(\mathrm{CW})$ as a fluorescent dye. $\mathrm{CW}$ binds to $\beta 1-3$ and $\beta 1-4$ 


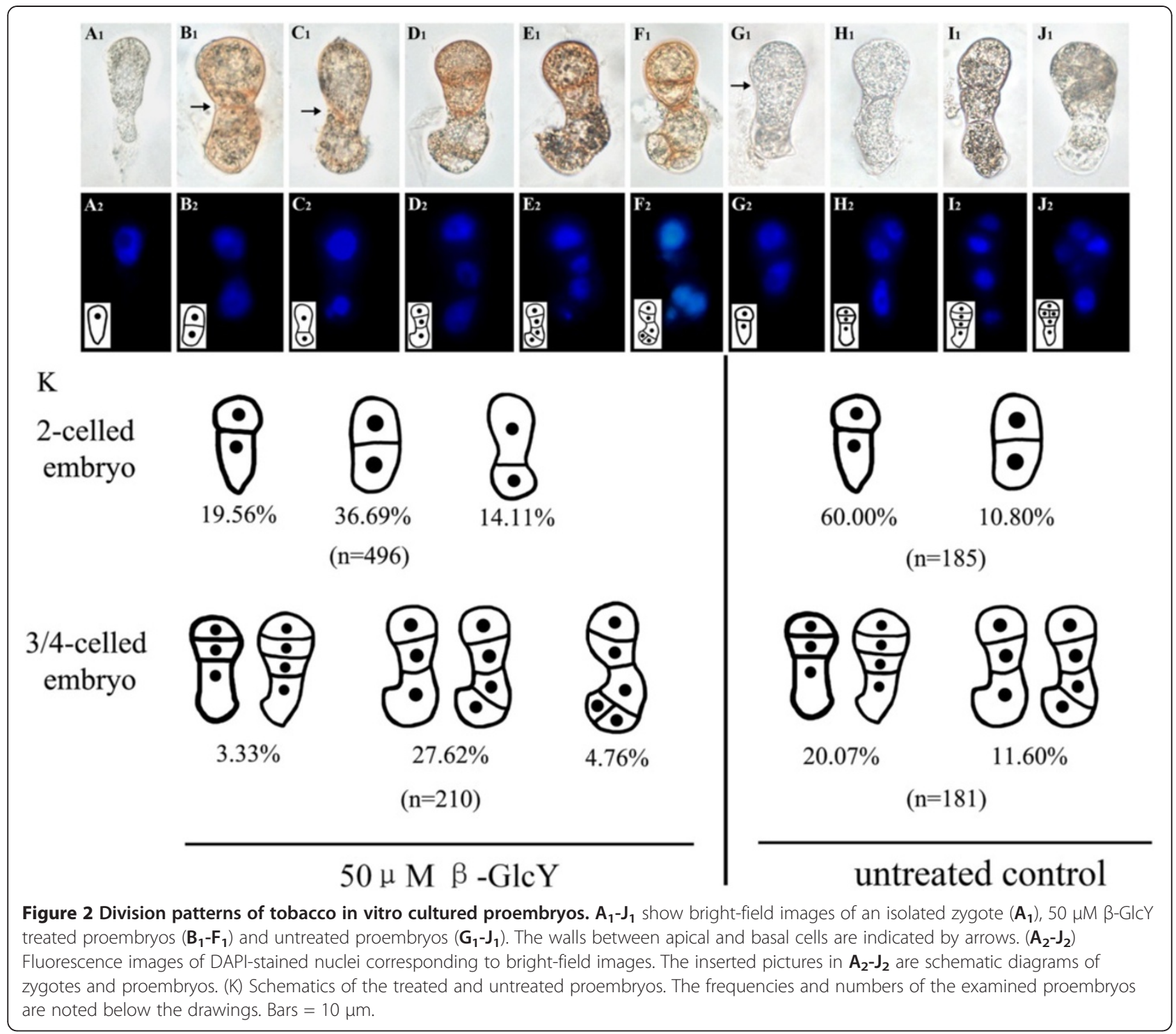

polysaccharides such as callose and cellulose, which are common components in plant cell walls. We stained both in vivo and in vitro samples with CW reagent and observed that the fluorescence labeling of the isolated proembryos in vivo (Figure $6 \mathrm{~A}_{1}-\mathrm{D}_{1}$ ) and untreated proembryos in vitro (Figure $6 \mathrm{G}_{1}$ ) was deposited abundantly in the cell plate wall. In proembryos cultured with $50 \mu \mathrm{M} \beta$-GlcY reagent, however, the CW fluorescence signal of cell plates was weaker or completely absent (Figure $6 \mathrm{E}_{1}, \mathrm{~F}_{1}$ ), instead, these regions were distinctly stained a red color with $\beta$-GlcY (Figure $6 \mathrm{E}_{2}$, $F_{2}$ ). Thus the $\beta$-GlcY treatment may affect the location of newly generated cell plate wall components.

\section{The influence of $\beta-G \mid c Y$ reagent on endocytosis} distribution

A fluorescent lipophilic styryl dye, FM4-64, is often used as an authentic endocytic marker in living plant cells
[43], and is taken up into the cell interior only by endocytosis and hence can gradually labels the endocytic pathway. To investigate the change in endomembrane structures, we used FM4-64 to stain the living zygotes and proembryos in vivo and in vitro. In the zygotes, the fluorescence of FM4-64 was equidistributed in the whole cytoplasm (Figure $7 \mathrm{~A}_{1}$ ). When zygotes divided into multi-cell embryos, the signal of FM4-64 was detected extensively among the newly formed cell plates and their edges (Figure $7 \mathrm{~B}_{1}-\mathrm{D}_{1}$ ). However, in $\beta$-GlcY treated proembryos, the specific signal at cell plate edges disappeared and was replaced by equidistribution or abnormal accumulation of the FM4-64 signal in the cytoplasm (Figure $7 \mathrm{E}_{1}, \mathrm{~F}_{1}$ ). In addition, in the proembryos cultured without $\beta$-GlcY, the newly formed cell plates were clearly labeled by FM4-64 (Figure 7G $1, \mathrm{H}_{1}$ ). It's well known that endocytic delivery of cell surface material significantly 


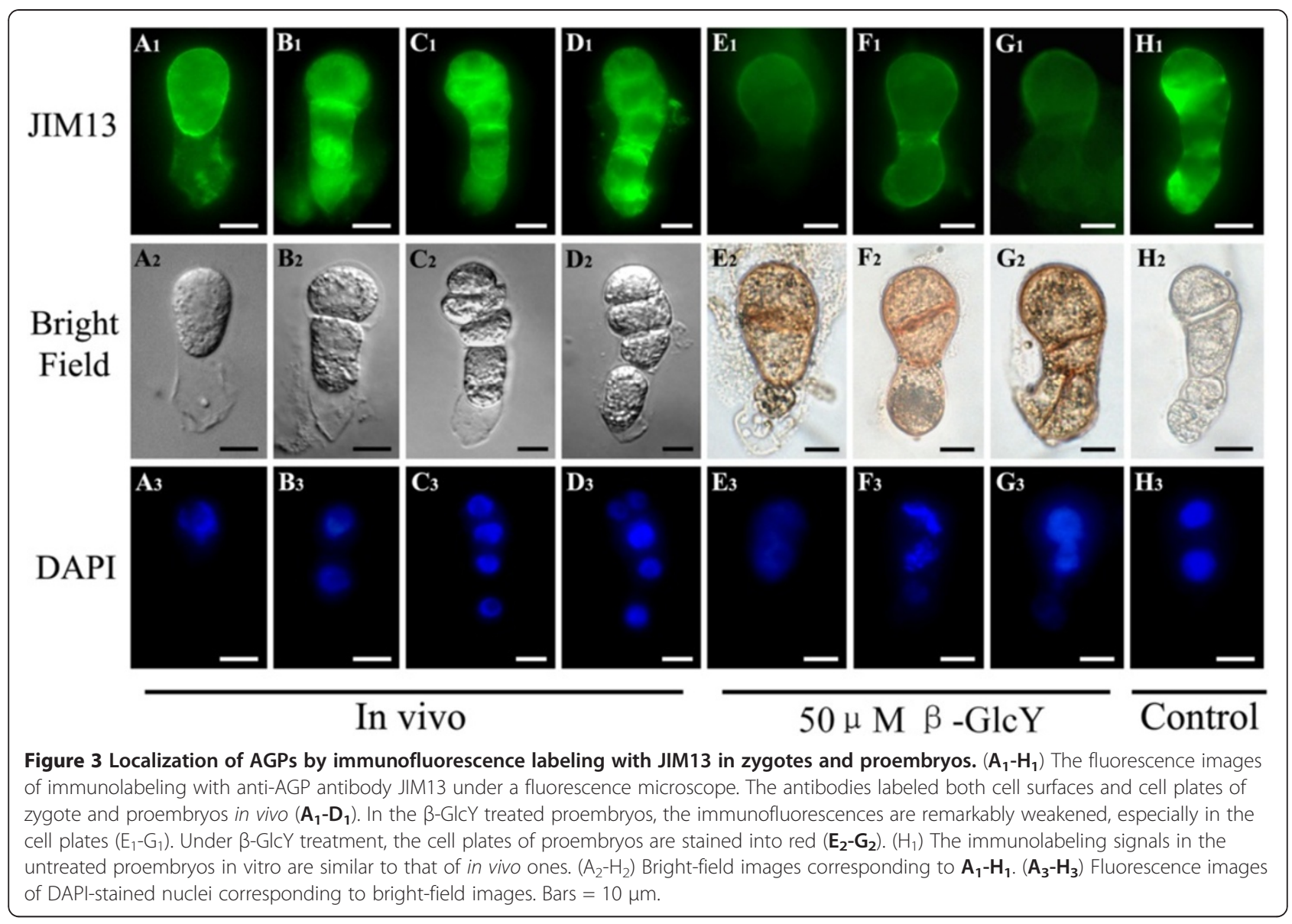

contributed to cell plate formation during cell division; hence the endosome distribution change induced by $\beta$ GlcY may suggest an important role of AGPs in cell plate formation.

\section{Ultrastructure characteristics in zygotes and proembryos}

The ultrastructure micrographs were acquired by transmission electron microscopy, and more details of zygotes and proembryos in vivo and in vitro were revealed in these pictures. In Figure 8A, the elongated, pyriform-shaped zygote in vivo in tobacco was highly polarized, with a large nucleus located in the chalazal end of the cell and some small vacuoles in the micropylar end, and starch-containing plastids greatly accumulated around the nucleus (Figure 8A). The first zygote division was transverse, producing a small spherical apical cell and a large basal cell (Figure $8 \mathrm{~B}$ ). In the in vivo two-celled embryos, there were numbers of endoplasmic reticulum (ER), plastids and mitochondria similar to the zygote (Figure 8D, E). Some endocytic vesicles were attached to the cell wall, and the others appeared nearby the cell plate region (Figure $8 \mathrm{C}$ ), indicating that endocytic vesicles were involved in cell plate formation. In vitro untreated proembryos showed similar features to in vivo proembryos (Figure 8J-L). However, the $\beta$-GlcY treated proembryo cells differed with both in vivo and in vitro non-treated proembryos-endosomes in the cell plate were not observed (Figure 8F-I). Thus, the results suggested that AGPs distribution might be involved in endocytic vesicles location and further in cell plate formation.

In $\beta$-GlcY treated proembryos, we also found that cellorganelles, such as plastids and mitochondria, showed morphological changes, and the number of ribosome decreased (Figure 8F-I). Then, we observed the ER and mitochondria distribution using the fluorescent dyes $\mathrm{DiOC}_{6}(3)$ and Rhodamine123, respectively (Figure 9), which gave similar results with those observed under transmission electron microscopy. The ER was evenly distributed in the cytoplasm of in vivo zygotes and proembryos (Figure $9 \mathrm{~A}_{1}-\mathrm{D}_{1}$ ). In vitro culture could change ER distribution either with (Figure $9 \mathrm{E}_{1}-\mathrm{F}_{1}$ ) or without $\beta-\mathrm{GlcY}$ treatment (Figure $9 \mathrm{G}_{1}$ ); however, the ER distribution was much more disordered in treated samples than those untreated. The mitochondria were distributed around the nucleus in cytoplasm of in vivo zygotes and proembryos (Figure $9 \mathrm{H}_{1}-\mathrm{K}_{1}$ ). For in vitro cultured samples, it displayed a disorderly distribution of mitochondria after $\beta$-GlcY 


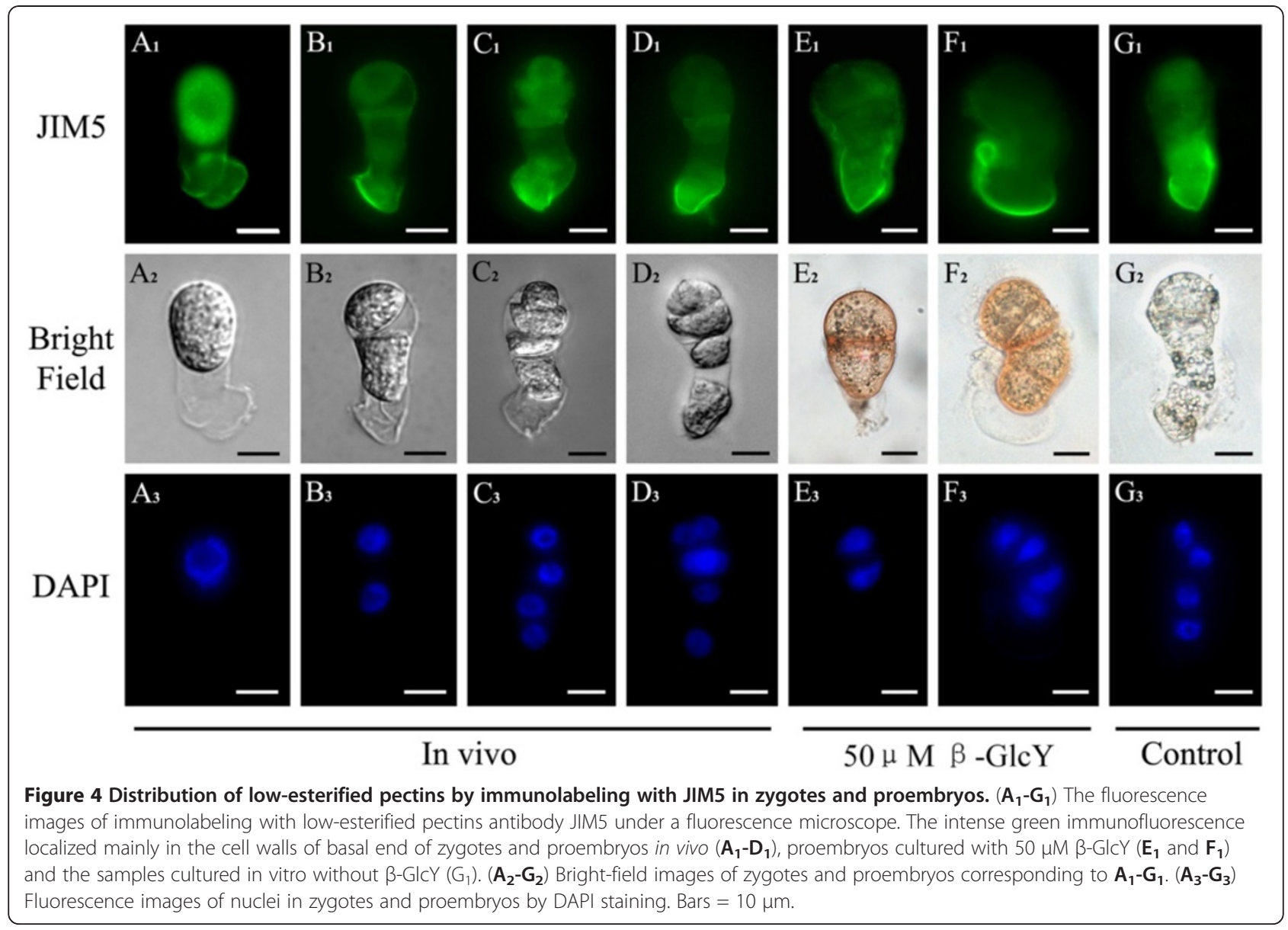

treatment (Figure $9 \mathrm{~L}_{1}-\mathrm{M}_{1}$ ), while mitochondria localization in untreated proembryos were similar to those in vivo (Figure $9 \mathrm{~N}_{1}$ ). Above all, $\beta$-GlcY not only affected the cell plate formation but also had influence on cell-organelle distribution, suggesting roles of AGPs in these processes.

\section{Discussion}

Angiosperm embryo development follows a predictable pattern of planes and numbers of cell divisions [3,21,42]. In the present study, we firstly examined the detailed division events of normal proembryo development in tobacco (Figure 1). Intriguingly, we also found that there are differences between N. tabacum and Arabidopsis in the initial division patterns of apical cells and in suspensor cell numbers. In tobacco, the resultant zygote elongated and then divided asymmetrically to form two daughter cells of different sizes (Figure $1 \mathrm{~A}_{1}, \mathrm{~B}_{1}$ ). The small apical daughter cell firstly underwent one transverse and then two rounds of longitudinal divisions to give rise to an eight-celled embryo proper (Figure $1 \mathrm{~F}_{1}$ ). While in another typical dicot Arabidopsis, the apical cell undergoes two longitudinal and then one transverse division to form an octant embryo proper [44]. Concurrently, the basal cell divides transversely to form a suspensor of 3-4 cells in tobacco, compared to 6-7 cells in the Arabidopsis suspensor.

The well-established experimental system of isolation and culture of tobacco zygotes and proembryos is propitious to investigating the early events and mechanism of dicotyledonous plant embryogenesis. Recently, some transcriptome research in tobacco zygotes and proembryos provided much data in zygote gene activation (ZGA) and embryo polarity establishment $[20,45,46]$. We also use the in vitro culture system with $\beta$-GlcY treatment, which could provide symmetrically divided proembryos compared with the symmetric ones in vivo, to study the early proembryo development. Besides the cellular study results we have shown in this paper, the molecular methods were also applied in order to uncover the mechanisms how zygote initiate the first asymmetric division. Recently, our transcriptome studies on $\beta$-GlcY treated zygotes and two-celled proembryos have identified some candidate genes might related to zygotic division and proembryonic development [39]. Therefore, combination of cytological and molecular approaches with genetic methods will give more investigation outcomes in early plant embryo development and fill more research gaps. 


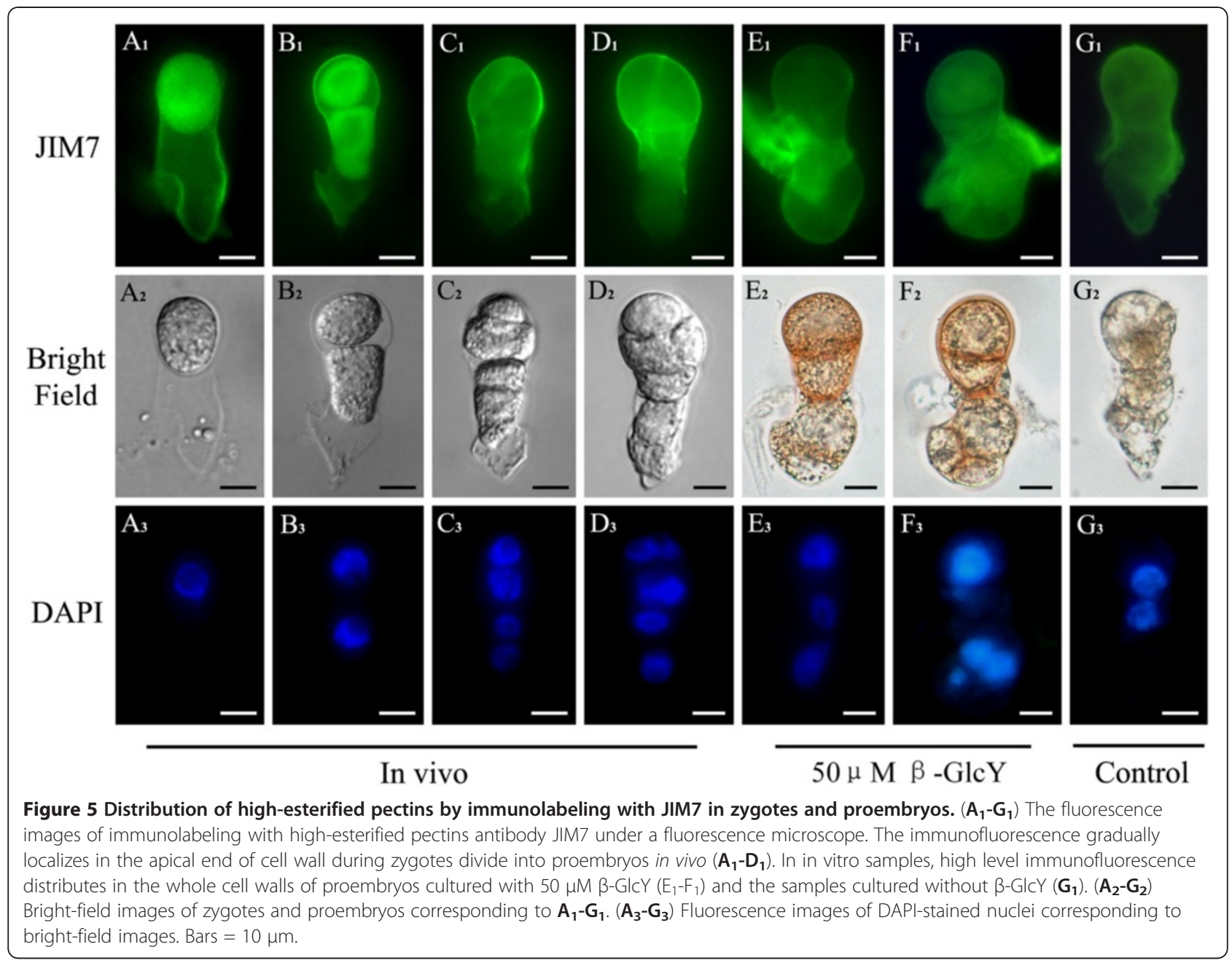

Possible roles of AGPs in the proembryonic cell fate decision

In dicotyledons, such as Arabidopsis and tobacco, the polarity of the proembryo was established as early as the first asymmetric zygote division. After that, the two daughter cells undergo distinct developmental fates. Previous researches have shown that the apical and basal cells were different in shape, size, cytoplasm and even in gene transcriptions $[20,42,44]$. In our studies, with $\beta$ GlcY treatment, the proper zygotic division and subsequent cell divisions of the proembryo were affected, and formed aberrant proembryos which had lost morphological polarity (Figure 2). Furthermore, the detailed effects induced by $\beta$-GlcY were observed by photomicrograph and electron microscope (Figure 2 and 8 ), and the results showed that the typical characteristics of apical cell, like relatively small size and dense cytoplasm were changed, concurrently, their developmental pathway deviates from the initial destiny. Some studies on zygotic embryogenesis of many different plants had also revealed that AGPs involved in maintenance of meristem cells, and the other researched in somatic embryogenesis also showed the involvement of AGPs in the induction of embryonic cells [15-18,47-50]. In microspore embryogenesis, it was also revealed that AGPs might be able to induce embryogenic proficiency [51]. In Arabidopsis, the result of our lab had displayed that $\beta$-GlcY treatment can change the shoot apical meristem cells in torpedostage embryo from typical meristem cells into differentiated cells, which contained more starch grains and larger vacuoles [18]. In early embryo stage of tobacco, we also found that $\beta$-GlcY treatment not only affected the cell division planes and relatively cell size, but also influenced subcellular structures (Figure 2 and 8), such as organelles abundance and distribution, which were the typical characteristics to distinguish the cell differentiation degree. Recently, our another research by comparative transcriptional analysis in $\beta$-GlcY treated and in vivo untreated two-celled proembryos indicated that the expression of some transcripts related to zygotic cell division and development was significantly different [39]. Above all, the significant influence of $\beta$-GlcY treatment 


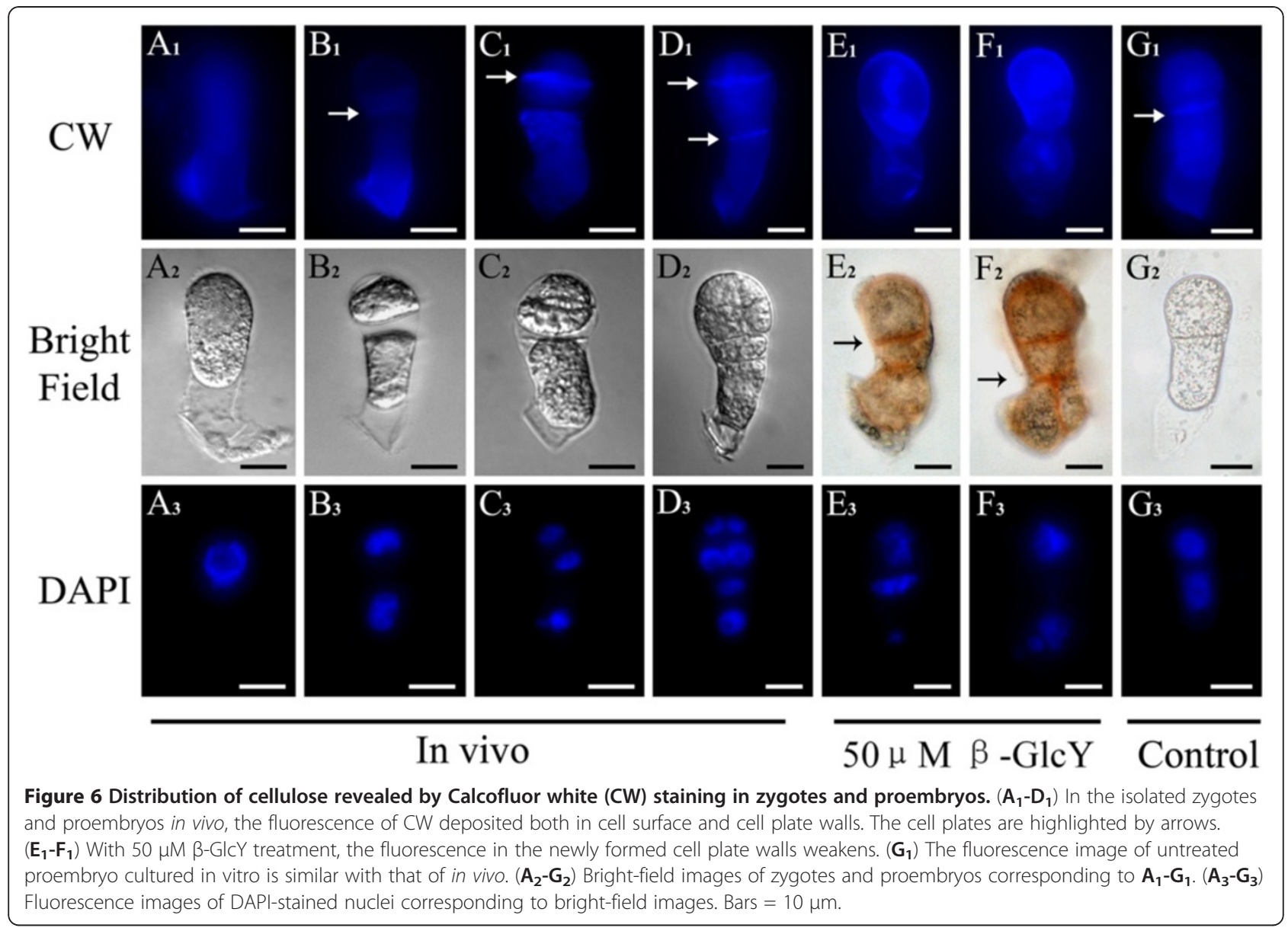

on the developmental fate of zygotic and somatic embryo cells suggest that AGPs might play important roles in these processes. However, the details of how AGPs are involved in proembryo cell fate decision still need more research.

\section{$\beta$-GlcY reagent affects new cell wall components accumulation in tobacco proembryo}

In the proembryos, like other organs of higher plants, the position of new cell plate determines whether the division is symmetrical or asymmetrical, and affects the subsequent differentiation and development of daughter cells. In our study, we found that AGPs were abundant in tobacco zygotes and proembryos, especially in the newly formed cell plate region (Figure 3). These results reveal that AGPs may be involved in cell plate location, which is pivotal for normal proembryo development of plants. Some studies have revealed that endocytic delivery significantly contributes to cell plate formation during plant cell division [22]. It's via endosomes that new cell wall components such as pectins and cell-wall-associated proteins (e.g. AGPs) are transferred to the margin of the cell plate [24-26]. Therefore, endosomes are involved in the execution of cytokinesis and the assembly of the cell wall. Previous research in lily pollen tubes showed that the secretory endosomes in the tips of pollen tubes were destabilized by $\beta$-GlcY reagent, and normal incorporation of cell wall components was prevented, which inhibited the tube tip growth [38]. In the present study, the accumulation of cellulose in newly formed cell plates was blocked by $\beta$-GlcY reagent (Figure 6). Furthermore, staining of endocytotic delivery with FM4-64 showed that the distribution of endosomal vesicles in cultured proembryo cells was disrupted by adding $\beta$-GlcY reagent (Figure 7 ). Our study indicates the the correlation of endosomal vesicles and cell plate formation, and suggest the involvement of AGPs in cell wall material localization.

Plant cells wall are highly sophisticated structures consisting of diverse polysaccharides, such as cellulose, hemicellulose, pectin, and structural proteins [24-26], and pectins are the major components of the primary cell wall in dicotyledonous plants [52]. Some researchers have shown that AGPs might relate with pectin distribution in plant cells [18]. However, we were surprised to find that pectins with different degrees of esterification displayed distinct polar distribution in the cell wall of zygotes and proembryos, and the polarity was not affected by $\beta$-GlcY treatment (Figures 4 and 5). Currently, little is known 


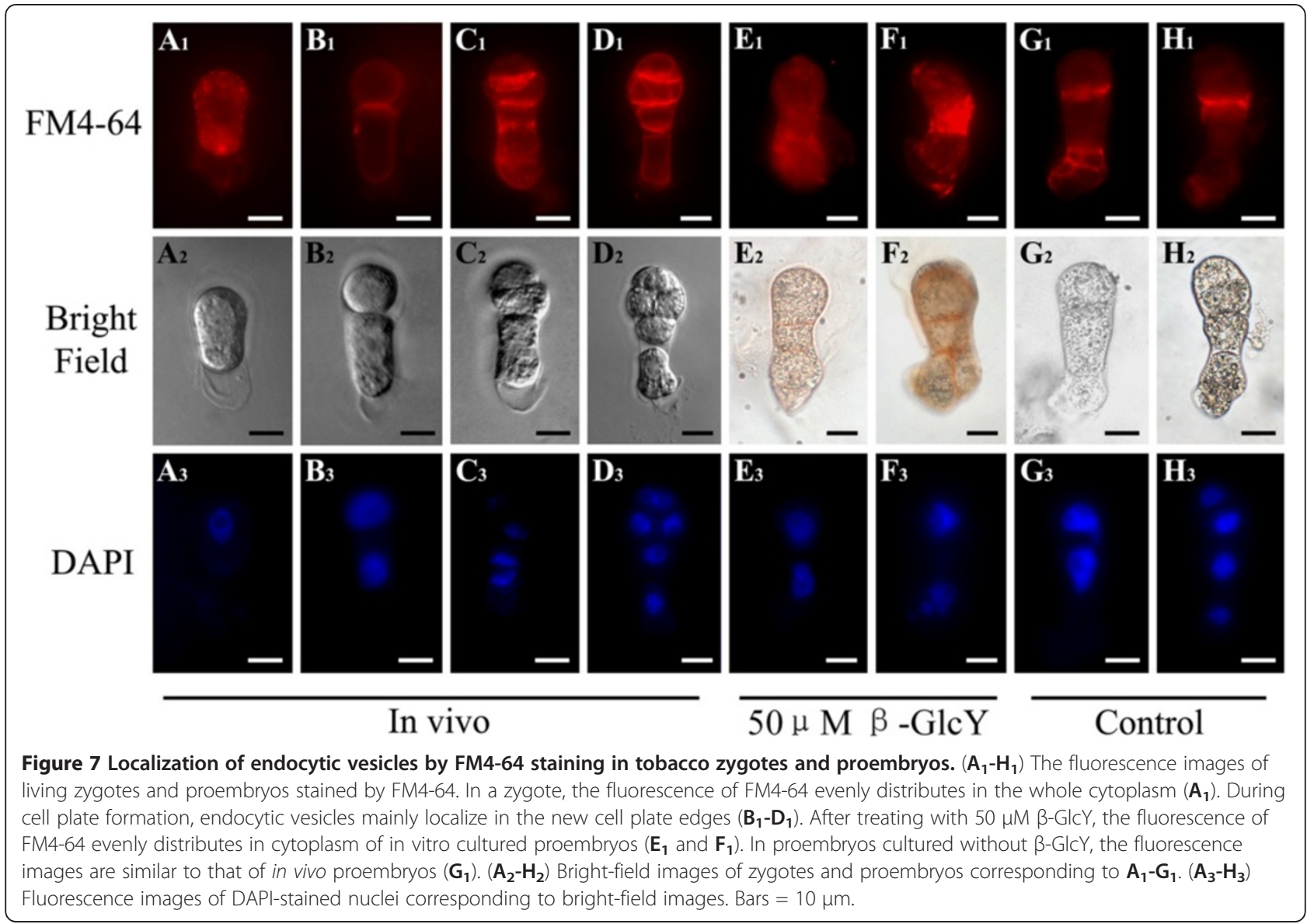

about the biosynthesis mechanism of pectins. It has been assumed that pectins are synthesized and methylesterified in the Golgi and secreted to the cell wall in a highly methyl-esterified form, and are subsequently deesterified by pectin methylesterases [53]. Immunolocalization in pollen tube showed that high-esterified pectins were exclusively present in the apical region of pollen tube walls, while low-esterified pectins widely distributed in the entire the tubes [54]. In addition, it was reported that the de-esterified pectins can bind $\mathrm{Ca}^{2+}$ ions and reinforce the cell wall structure [55]. In our study, JIM5 labeled lowesterified pectins were mainly localized in the basal end of tobacco zygote and proembryo cell wall in vivo; conversely, JIM7 recognized high-esterified pectins mainly distributed in the apical end of the cell wall (Figures 4A-D and 5A-D). Combined with previous studies, our observation in tobacco proembryos in vivo suggest that JIM7 recognized high-esterified pectins may be involved in the polar growth of proembryos, while the basal distributed low-esterified pectins may structurally rigidify the cell wall. However, the detailed mechanism of this interesting polar distribution of pectin in tobacco proembryos still need more research. Furthermore, in contrast to lowesterified pectins, the distribution patterns of high- esterified pectins differed between in vivo and in vitro cultured samples (Figure 5). Thus the pattern change of high-esterified pectins may be also associated with in vitro culture, not only with $\beta$-GlcY treatment.

\section{The possible model of AGPs involved in cell plate} formation during proembryo development

In the brown algae Fucus, the first asymmetrical cell division is associated with targeted secretion of cell wall components. Actin microfilaments and an intact cell wall are both required for directional vesicle secretion to stabilize its polar axis [56-58]. Some researchers demonstrated that $\beta$-GlcY treatment depolymerized and disorganized cortical microtubules in Brigit Yellow-2 (BY-2) cells and affected the organization of the F-actin $[59,60]$. Another group reported that cross-linking of AGPs with $\beta$-GlcY would result in inhibition of tobacco cell elongation, and proposed that AGPs were probably important regulators of plant cell growth [61]. It is well known that endosomal movement in plant cells is dependent on transportation of cytoskeleton network [62]. The present study suggests that the $\beta$-GlcY reagent entered the cell wall, bound to AGPs and formed AGP-Yariv complexes, thereby disrupting interactions of AGPs with other 

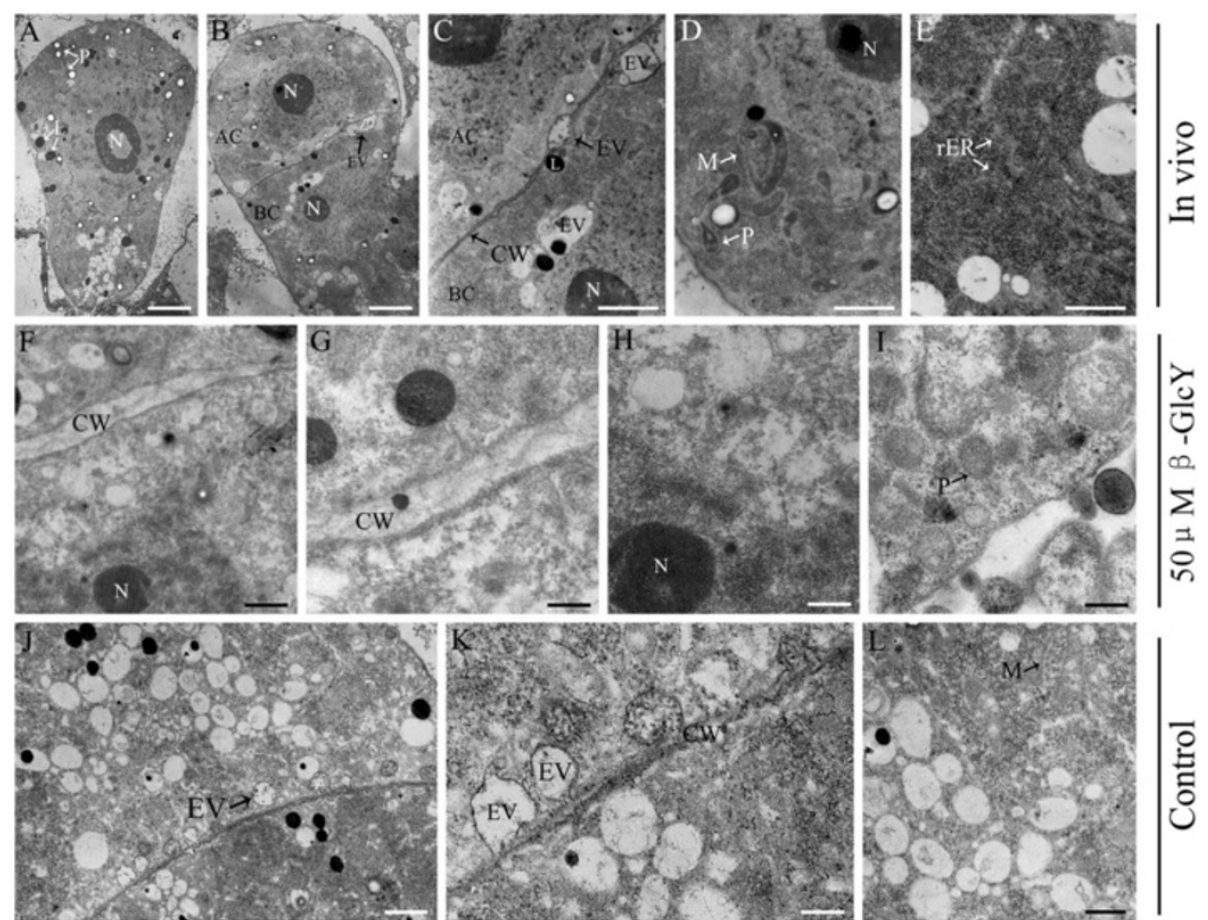

Figure 8 Transmission electron micrographs of tobacco zygotes and proembryos. (A) Ultrathin section of a zygote at $84 \mathrm{~h}$ after pollination. The plastids, vesicles and lipid bodies are highlighted with adjacent arrows. Bar $=3 \mu \mathrm{m}$. (B) The two-celled proembryo with an apical cell and a basal cell. Bar $=3 \mu \mathrm{m}$. (C) The local amplification of figure B shows plasma membrane and cell wall between apical and basal cells. Some endocytic vesicles localize in cell plate and are highlighted with arrows. Bar $=1 \mu \mathrm{m}$. (D) Cytoplasm in a proembryos in vivo. The plastids, mitochondria and rough-endoplasmic reticulum are highlighted with adjacent arrows. Bar $=1 \mu \mathrm{m}$. (E) Cytoplasm in a proembryos in vivo. Bar $=$ $500 \mathrm{~nm}$. (F-l) Ultrathin section images of $50 \mu \mathrm{M} \beta$-GlcY treated proembryos. After treatment with $\beta$-GlcY, the localization of endocytic vesicles in cell plates is affected ( $\mathbf{F}$ and $\mathbf{G})$. The distribution and morphology of cell organelles in $\beta$-GlcY treated proembryos are also changed ( $\mathbf{H}$ and $\mathbf{I})$. Bars $=500 \mathrm{~nm}$ in (F); $200 \mathrm{~nm}$ in $\mathbf{( G , H}$ and $\mathbf{~ I ) . ~ ( J - L ) ~ U l t r a t h i n ~ s e c t i o n ~ o f ~ i n ~ v i t r o ~ c u l t u r e d ~ p r o e m b r y o ~ w i t h o u t ~} \beta$-GlcY treatment. Some endocytic vesicles localize in cell plate and the pattern is similar with in vivo proembryos. Bars $=500 \mathrm{~nm}$ in (J); $200 \mathrm{~nm}$ in (K and L). AC, apical cell; BC, basal cell; CW, cell wall; rER, rough-endoplasmic reticulum; L, lipid body; M, mitochondrion; $N$, nucleus; P, plastid; EV, endocytic vesicle.

molecular components in the cell wall and plasma membrane, and finally obstructing endocytotic delivery and cytoskeleton transportation $[63,64]$. The other studies showed that AGPs may be involved in cellulose deposition in plant cells [65]. The previous works of our laboratory showed that the fasciclin-like arabinogalactan proteins FLA3 in Arabidopsis participated in pollen intine formation and may be involved in cellulose deposition [66], and that AGPs were involved in cell wall cellulose and pectin deposition in Arabidopsis embryos [18]. For in vitro culture of Arabidopsis ovules, $50 \mu \mathrm{M}$ $\beta$-GlcY treatment affected cellulose and pectin deposition, leading to abnormal cell division and cotyledon formation during embryo development. All these results suggest that AGPs play important roles in cell wall organization and cell division in reproductive plant development, though the detailed mechanisms of AGPs functions are future topics for study.

Based on the previous $[38,59,65]$ and present studies, a model of AGP involvement in cell plate formation was proposed (Figure 10). AGPs are abundant cell-surface proteins in plants and any AGP changes may affect other cell surface components or induce cytoskeletal abnormality $[27,60,67]$. In the zygotic embryogenesis, the loss of AGPs profoundly alters the first zygotic division and disarranges the proembryo pattern formation [15]. Our model suggests that after AGPs were bound by $\beta$-GlcY regent then might inhibit the interactions of AGPs with other molecules, thus may directly or indirectly affect cytoskeleton localization and disturb cytoskeleton-dependent transfer such as endocytotic delivery, and then further effects cell plate formation. Another possible model involved in this process is that AGP-Yariv complexes may disorder the assembly of the new cell wall and plasma membrane components, such as cellulose synthase (CSAs) [65]. Previous results in Arabidopsis have shown that the primary cell walls formation was effected and the cell elongation in the embryo axis was severely impaired in the null mutant of cellulose synthase $A$ [68]. In this case, the AGPs may have two important responsibilities: one as signaling 


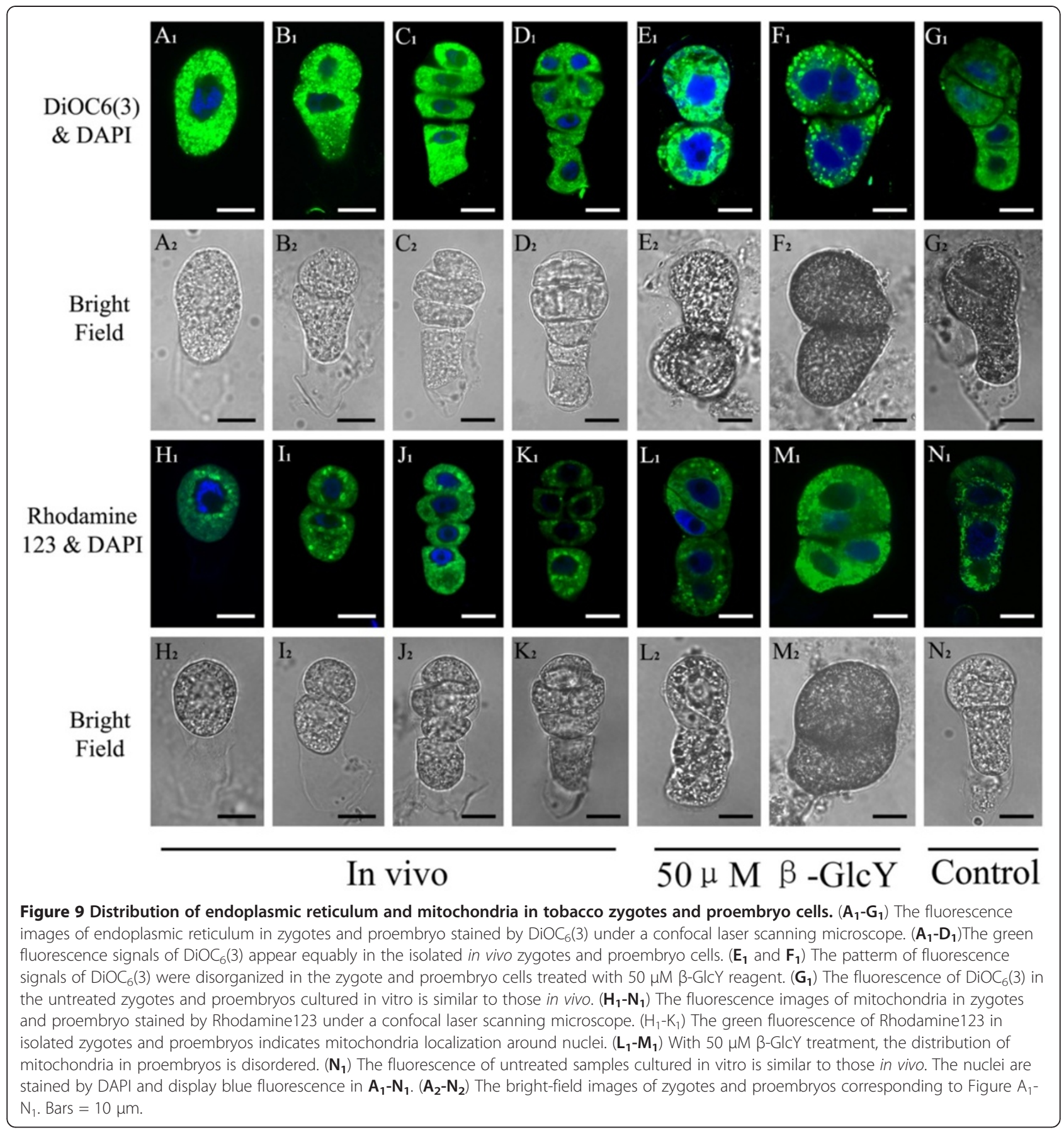

molecules and the other as structural components. However, the two possible functions of AGPs in zygotic division still need to be corroborated by more experimental evidence.

\section{Conclusions}

Here, we used in vitro zygote culture and series of meticulous cell biology techniques to investigate the AGPs roles in tobacco proembryo cell division. In tobacco, for the first time, we carried out the detailed observation on each cell division event of zygote and proembryo, and compared the subtle differences between tobacco proembryo division patterns and those of Arabidopsis. In in vitro cultured proembryos, we found that in the case of AGPs were specific binding with $\beta$-GlcY and lost their functions, the cell divisions of zygotes and proembryos were disordered. Furthermore, we used fluorescent labeling approaches combined with ultrathin sections to observe the distribution of AGPs, cell wall materials such as pectin and cellulose, endocytic vesicles and other cell-organelles. The 


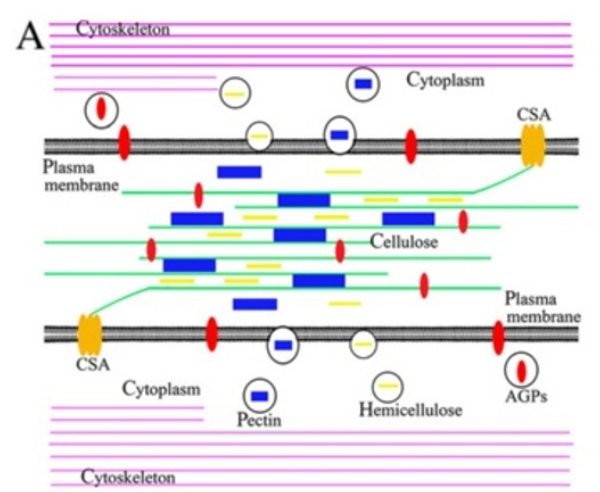

B
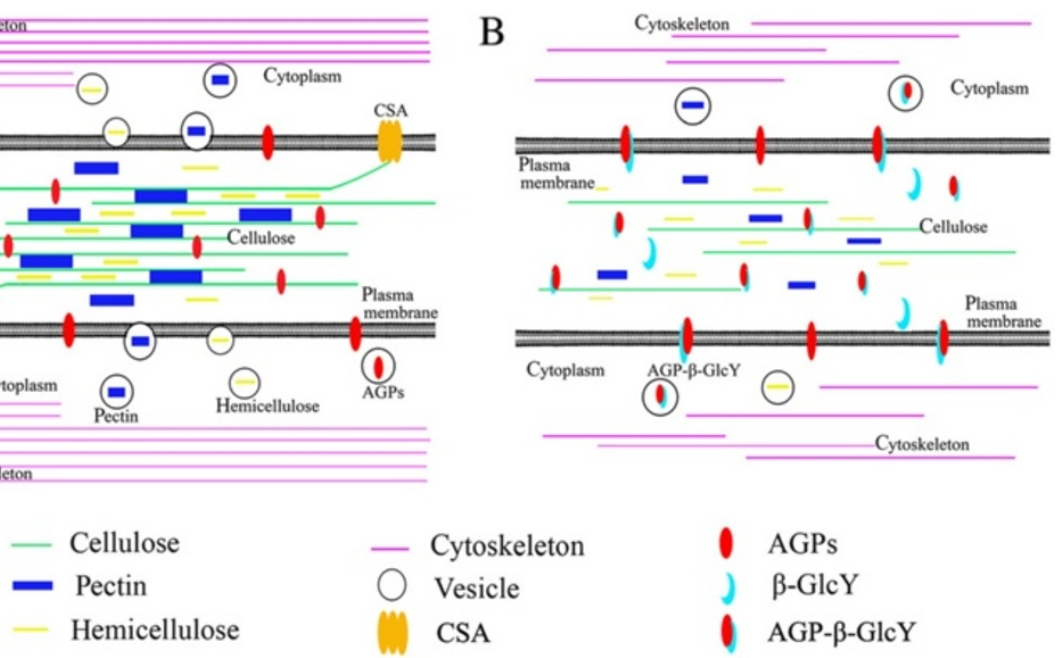

Figure 10 A hypothetical model for how AGPs involve in early proembryo cells division. (A) A possible in vivo model of cell plate formation. Cellulose synthesized by a complex of cellulose synthases (CSAs) on plasma membrane. Pectin and hemicellulose synthesized and secreted through the endomembrane system. Some types of AGPs anchor to membrane and some were directly secreted into cell wall space. Cytoskeleton networks transport endocytic vesicles to the correct site under the plasma membrane. (B) A possible in vitro model under $\beta$-GlcY treatment. $\beta$-GICY reagent binds with AGPs to form an AGP- $\beta$-GIcY complex. Cell wall components and cytoskeleton network could be disorganized with $\beta$-GlcY treatment, which affects new cell plate formation.

results showed that the cell plate specific location of AGPs, cellulose and endocytic vesicles were reduced or disorganized by the addition of an AGPs inhibitor, $\beta$-GlcY. In addition, the morphology and distribution of mitochondria and endoplasmic reticulum were both affected. Besides above findings, interestingly, we also found that low- and high-esterified pectins located in opposite positions of zygotes and proembryos and this polarity was hardly affected by $\beta$-GlcY. Based on our results, we may conclude that the cell plate positions decision and new cell wall materials location in vitro cultured zygotes and proembryos were both affected by $\beta$-GlcY treatment. These results imply that AGPs may contribute to the formation of the new cell plate, and suggest that AGPs play roles in some important developmental events of tobacco, including zygotic division and proembryo pattern establishment. Further molecular and genetic analysis will promote more promising research on mechanism of AGPs in plant development.

\section{Abbreviations}

AGPs: Arabinogalactan proteins; $\beta$-GlcY: $\beta$-glucosyl Yariv; BSA: Bovine serum albumin; CLSM: Confocal laser scanning microscopy; CSAs: Cellulose synthase; CW: Calcofluor white; DAP: Days after pollination; DAPI: 4,6diamidino-2-phenylindole; $\mathrm{DiOC}_{6}(3)$ : 3,3'-dihexyloxacarbocyanine iodide; DMSO: Dimethyl sulfoxide; FLA: Fasciclin-like arabinogalactan proteins; FM464: N-(3-triethylammoniumpropyl)-4- (p-diethylam-inophenylhexatrienyl)phridinium-2Br; HG: Homogalacturonan; PHP: Phragmoplast; PMEs: Pectin methylesterases; PPB: Preprophase band; RG-I: Rhamnogalacturonan-l; SG: Substituted galacturonans; ZGA: Zygote gene activation.

\section{Authors' contributions}

MY carried out the experiment, participated in the design of the study and drafted the manuscript. JZ conceived of the study, and participated in its design and helped to draft the manuscript. Both authors read and approved the final manuscript.

\section{Acknowledgements}

We thank Dr J. P. Knox (Centre for Plant Sciences, University of Leeds, UK) for the generous gifts of the antibodies. This project was supported by the National Natural Science Foundation of China (30970277, 31170171), the Key Grant Project of Chinese Ministry of Education (311026), and the Special Doctorial Program Funds of the Ministry of Education of China

(20090141110035)

Received: 23 May 2012 Accepted: 12 July 2012

Published: 1 August 2012

\section{References}

1. Goldberg RB, de Paiva G, Yadegari R: Plant embryogenesis: zygote to seed. Science 1994, 266:605-614.

2. Jenik PD, Gillmor CS, Lukowitz W: Embryonic patterning in Arabidopsis thaliana. Annu Rev Cell Dev Biol 2007, 23:207-236.

3. Park S, Harada JJ: Arabidopsis embryogenesis. Methods Mol Biol 2008, 427:3-16.

4. De Smet I, Lau S, Mayer U, Jurgens G: Embryogenesis - the humble beginnings of plant life. Plant I 2010, 61:959-970.

5. Souter M, Lindsey K: Polarity and signalling in plant embryogenesis. J Exp Bot 2000, 51:971-983.

6. Jurgens G: Apical-basal pattern formation in Arabidopsis embryogenesis. EMBO J 2001, 20:3609-3616.

7. Laux T, Wurschum T, Breuninger H: Genetic regulation of embryonic pattern formation. Plant Cell 2004, 16:190-202.

8. Weterings K, Apuya NR, Bi Y, Fischer RL, Harada JJ, Goldberg RB: Regional localization of suspensor mRNAs during early embryo development. Plant Cell 2001, 13:2409-2425

9. Chaudhury AM, Craig S, Dennis E, Peacock W: Ovule and embryo development, apomixis and fertilization. Curr Opin Plant Biol 1998, 1:26-31.

10. Hoshino $Y$, Murata N, Shinoda K: Isolation of individual egg cells and zygotes in Alstroemeria followed by manual selection with a microcapillary-connected micropump. Ann Bot 2006, 97:1139-1144.

11. Hoshino Y, Scholten S, von Wiegen P, Lorz H, Kranz E: Fertilization-induced changes in the microtubular architecture of the maize egg cell and zygote-an immunocytochemical approach adapted to single cells. Sex Plant Reprod 2004, 17:89-95. 
12. Le Q, Gutierrez-Marcos JF, Costa LM, Meyer S, Dickinson HG, Lorz H, Kranz E, Scholten S: Construction and screening of subtracted cDNA libraries from limited populations of plant cells: a comparative analysis of gene expression between maize egg cells and central cells. Plant J 2005, 44:167-178

13. Leduc N, Matthys-Rochon E, Rougier M, Mogensen L, Holm P, Magnard JL, Dumas $C$ : Isolated maize zygotes mimic in vivo embryonic development and express microinjected genes when cultured in vitro. Dev Biol 1996, 177:190-203.

14. Sprunck S, Baumann U, Edwards K, Langridge P, Dresselhaus T: The transcript composition of egg cells changes significantly following fertilization in wheat (Triticum aestivum L.). Plant J 2005, 41:660-672.

15. Qin $Y$, Zhao J: Localization of arabinogalactan proteins in egg cells, zygotes, and two-celled proembryos and effects of beta-D-glucosyl Yariv reagent on egg cell fertilization and zygote division in Nicotiana tabacum L. J Exp Bot 2006, 57:2061-2074.

16. Hu Y, Qin Y, Zhao J: Localization of an arabinogalactan protein epitope and the effects of Yariv phenylglycoside during zygotic embryo development of Arabidopsis thaliana. Protoplasma 2006, 229:21-31.

17. Zhang XL, Ren YJ, Zhao J: Roles of extensins in cotyledon primordium formation and shoot apical meristem activity in Nicotiana tabacum. J Exp Bot 2008, 59:4045-4058

18. Zhong J, Ren YJ, Yu M, Ma TF, Zhao J: Roles of arabinogalactan proteins in cotyledon formation and cell wall deposition during embryo development of Arabidopsis. Protoplasma 2011, 248:551-563.

19. He YC, He YQ, Qu LH, Sun MX, Yang HY: Tobacco zygotic embryogenesis in vitro: the original cell wall of the zygote is essential for maintenance of cell polarity, the apical-basal axis and typical suspensor formation. Plant J 2007, 49:515-527.

20. Hu TX, Yu M, Zhao J: Comparative transcriptional profiling analysis of the two daughter cells from tobacco zygote reveals the transcriptome differences in the apical and basal cells. BMC Plant Biol 2010, 10:167.

21. Abrash EB, Bergmann DC: Asymmetric cell divisions: a view from plant development. Dev Cell 2009, 16:783-796.

22. Dhonukshe P, Baluska F, Schlicht M, Hlavacka A, Samaj J, Friml J, Gadella TW Jr: Endocytosis of cell surface material mediates cell plate formation during plant cytokinesis. Dev Cell 2006, 10:137-150.

23. Samuels AL, Giddings TH, Staehelin LA Jr: Cytokinesis in tobacco BY-2 and root tip cells: a new model of cell plate formation in higher plants. J Cell Biol 1995, 130:1345-1357.

24. Jurgens G: Plant cytokinesis: fission by fusion. Trends Cell Biol 2005, 15:277-283.

25. Samaj J, Read ND, Volkmann D, Menzel D, Baluska F: The endocytic network in plants. Trends Plant Sci 2005, 15:425-433.

26. Shibaya T, Sugawara Y: Induction of multinucleation by beta-glucosyl Yariv reagent in regenerated cells from Marchantia polymorpha protoplasts and involvement of arabinogalactan proteins in cell plate formation. Planta 2009, 230:581-588.

27. Ellis M, Egelund J, Schultz CJ, Bacic A: Arabinogalactan-proteins: key regulators at the cell surface. Plant Physiol 2010, 153:403-419.

28. $\mathrm{Lu} \mathrm{H}$, Chen M, Showalter AM: Developmental expression and perturbation of arabinogalactan-proteins during seed germination and seedling growth in tomato. Physiol Plant 2001, 112:442-450.

29. Ma HL, Zhao J: Genome-wide identification, classification, and expression analysis of the arabinogalactan protein gene family in rice (Oryza sativa L.). J Exp Bot 2010, 61:2647-2668.

30. Pan X, Yang X, Lin G, Zou R, Chen H, Samaj J, Xu C: Ultrastructural changes and the distribution of arabinogalactan proteins during somatic embryogenesis of banana (Musa spp. AAA cv. 'Yueyoukang 1'). Physiol Plant 2011, 142:372-389.

31. Schultz CJ, Johnson KL, Currie G, Bacic A: The classical arabinogalactan protein gene family of Arabidopsis. Plant Cell 2000, 12:1751-1768.

32. van Hengel AJ, Tadesse Z, Immerzeel P, Schols H, van Kammen A, de Vries SC: $\mathrm{N}$-acetylglucosamine and glucosamine-containing arabinogalactan proteins control somatic embryogenesis. Plant Physiol 2001, 125:1880-1890.

33. Coimbra S, Almeida J, Junqueira V, Costa ML, Pereira LG: Arabinogalactan proteins as molecular markers in Arabidopsis thaliana sexual reproduction. J Exp Bot 2007, 58:4027-4035

34. Gao M, Showalter AM: Immunolocalization of LeAGP-1, a modular arabinogalactan-protein, reveals its developmentally regulated expression in tomato. Planta 2000, 210:865-874
35. Showalter AM: Arabinogalactan-proteins: structure, expression and function. Cell Mol Life Sci 2001, 58:1399-1417.

36. Nothnagel EA: Proteoglycans and related components in plant cells. Int Rev Cytol 1997, 174:195-291.

37. Yariv J, Raport MM, Graf L: The interaction of glycosides and saccharides with antibody to the corresponding phenylazo glycosides. Biochem J 1962, 85:383-388.

38. Roy S, Jauh GY, Hepler PK, Lord EM: Effects of Yariv phenylglycoside on cell wall assembly in the lily pollen tube. Planta 1998, 204:450-458.

39. Hu TX, Yu M, Zhao J: Comparative transcriptional analysis reveals differential gene expression between asymmetric and symmetric zygotic divisions in tobacco. PLoS One 2011, 6:e27120.

40. Li ST, Yang HY: Gene transfer into isolated and cultured tobacco zygotes by a specially designed device for electroporation. Plant Cell Rep 2000, 19:1184-1187.

41. Clausen MH, Willats WG, Knox JP: Synthetic methyl hexagalacturonate hapten inhibitors of anti-homogalacturonan monoclonal antibodies LM7, JIM5 and JIM7. Carbohydr Res 2003, 338:1797-1800.

42. Smith LG: Plant cell division: building walls in the right places. Nat Rev Mol Cell Biol 2001, 2:33-39.

43. Bolte $\mathrm{S}$, Talbot $\mathrm{C}$, Boutte $Y$, Catrice O, Read ND, Satiat-Jeunemaitre B: FMdyes as experimental probes for dissecting vesicle trafficking in living plant cells. J Microsc-Oxford 2004, 214:159-173.

44. Hamann T, Mayer $U$, Jurgens $G$ : The auxin-insensitive bodenlos mutation affects primary root formation and apical-basal patterning in the Arabidopsis embryo. Development 1999, 126:1387-1395.

45. Ma L, Xin H, Qu L, Zhao J, Yang L, Zhao P, Sun M: Transcription profile analysis reveals that zygotic division results in uneven distribution of specific transcripts in apical/basal cells of tobacco. PLoS One 2011, 6:e15971.

46. Zhao J, Xin H, Qu L, Ning J, Peng X, Yan T, Ma L, Li S, Sun MX: Dynamic changes of transcript profiles after fertilization are associated with de novo transcription and maternal elimination in tobacco zygote, and mark the onset of the maternal-to-zygotic transition. Plant J 2011, 65:131-145.

47. Stacey NJ, Roberts K, Knox JP: Patterns of expression of the JIM4 arabinogalactanprotein epitope in cell-cultures and during somatic embryogenesis in Daucus carota L. Planta 1990, 180:285-292.

48. Toonen MAJ, Schmidt EDL, Hendriks T, Verhoeven HA, van Kammen A, deVries SC: Expression of the JIM8 cell wall epitope in carrot somatic embryogenesis. Planta 1996, 200:167-173.

49. Chapman A, Blervacq AS, Vasseur J, Hilbert JL: Arabinogalactan-proteins in Cichorium somatic embryogenesis: effect of $\beta$-glucosyl Yariv reagent and epitope localisation during embryo development. Planta 2000, 211:305-314.

50. McCabe PF, Valentine TA, Forsberg LS, Pennell Rl: Soluble signals from cells identified at the cell wall establish a developmental pathway in carrot. Plant Cell 1997, 9:2225-2241.

51. Tang $X C$, He YQ, Wang $Y$, Sun MX: The role of arabinogalactan proteins binding to Yariv reagents in the initiation, cell developmental fate, and maintenance of microspore embryogenesis in Brassica napus L. CV. Topas. J Exp Bot 2006, 57:2639-2650.

52. Caffall KH, Mohnen D: The structure, function, and biosynthesis of plant cell wall pectic polysaccharides. Carbohydr Res 2009, 344:1879-1900.

53. Pelloux J, Rusterucci C, Mellerowicz EJ: New insights into pectin methylesterase structure and function. Trends Plant Sci 2007, 12:267-277.

54. Bosch M, Cheung AY, Hepler PK: Pectin methylesterase, a regulator of pollen tube growth. Plant Physiol 2005, 138:1334-1346.

55. Ridley BL, O'Neill MA, Mohnen D: Pectins: structure, biosynthesis, and oligogalacturonide-related signaling. Phytochemistry 2001, 57:929-967.

56. Belanger KD, Quatrano RS: Membrane recycling occurs during asymmetric tip growth and cell plate formation in Fucus distichus zygotes. Protoplasma 2000, 212:24-37.

57. De Smet I, Beeckman T: Asymmetric cell division in land plants and algae: the driving force for differentiation. Nat Rev Mol Cell Biol 2011, 12:177-188.

58. Hadley R, Hable WE, Kropf DL: Polarization of the endomembrane system is an early event in fucoid zygote development. BMC Plant Biol 2006, 6:5.

59. Sardar HS, Yang J, Showalter AM: Molecular interactions of arabinogalactan proteins with cortical microtubules and F-actin in Bright Yellow-2 tobacco cultured cells. Plant Physiol 2006, 142:1469-1479.

60. Sardar HS, Showalter AM: A Cellular Networking Model Involving Interactions Among Glycosyl-Phosphatidylinositol (GPI)-Anchored Plasma 
Membrane Arabinogalactan Proteins (AGPs), Microtubules and F-actin in Tobacco BY-2 Cells. Plant Signal Behav 2007, 2:8-9.

61. Vissenberg K, Feijo JA, Weisenseel MH, Verbelen JP: Ion fluxes, auxin and the induction of elongation growth in Nicotiana tabacum cells. J Exp Bot 2001, 52:2161-2167.

62. Barr FA, Gruneberg U: Cytokinesis: Placing and making the final cut. Cell 2007, 131:847-860

63. Baluska F, Samaj J, Wojtaszek P, Volkmann D, Menzel D: Cytoskeletonplasma membrane-cell wall continuum in plants. Emerging links revisited. Plant Physiol 2003, 133:482-491.

64. Kohorn BD: Plasma membrane-cell wall contacts. Plant Physiol 2000, 124:31-38.

65. Kohorn BD: WAKs; cell wall associated kinases. Curr Opin Cell Biol 2001, 13:529-533.

66. Li J, Yu M, Geng LL, Zhao J: The fasciclin-like arabinogalactan protein gene, FLA3, is involved in microspore development of Arabidopsis. Plant I 2010, 64:482-497.

67. Sun W, Zhao ZD, Hare MC, Kieliszewski MJ, Showalter AM: Tomato LeAGP-1 is a plasma membrane-bound, glycosylphosphatidylinositol-anchored arabinogalactan-protein. Physiol Plant 2004, 120:319-327.

68. Beeckman T, Przemeck GK, Stamatiou G, Lau R, Terryn N, De Rycke R, Inze D, Berleth $\mathrm{T}$ : Genetic complexity of cellulose synthase a gene function in Arabidopsis embryogenesis. Plant Physiol 2002, 130:1883-1893.

doi:10.1186/1471-2229-12-126

Cite this article as: Yu and Zhao: The cytological changes of tobacco zygote and proembryo cells induced by beta-glucosyl Yariv reagent suggest the involvement of arabinogalactan proteins in cell division and cell plate formation. BMC Plant Biology 2012 12:126.

\section{Submit your next manuscript to BioMed Central and take full advantage of:}

- Convenient online submission

- Thorough peer review

- No space constraints or color figure charges

- Immediate publication on acceptance

- Inclusion in PubMed, CAS, Scopus and Google Scholar

- Research which is freely available for redistribution 